University of Nebraska - Lincoln

DigitalCommons@University of Nebraska - Lincoln

1988

\title{
Effect of Wheat Streak Mosaic Virus Infection on Total DNA and Chloroplast Ribosomal RNA in Wheat Leaves
}

Myron K. Brakke

University of Nebraska-Lincoln

J. L. White

BARC-West

R. G. Samson

Oregon State University

J. Joshi

NHLBI

Follow this and additional works at: https://digitalcommons.unl.edu/plantpathpapers

Part of the Plant Pathology Commons

Brakke, Myron K.; White, J. L.; Samson, R. G.; and Joshi, J., "Effect of Wheat Streak Mosaic Virus Infection on Total DNA and Chloroplast Ribosomal RNA in Wheat Leaves" (1988). Papers in Plant Pathology. 172. https://digitalcommons.unl.edu/plantpathpapers/172

This Article is brought to you for free and open access by the Plant Pathology Department at DigitalCommons@University of Nebraska - Lincoln. It has been accepted for inclusion in Papers in Plant Pathology by an authorized administrator of DigitalCommons@University of Nebraska - Lincoln. 


\title{
Effect of Wheat Streak Mosaic Virus Infection on Total DNA and Chloroplast Ribosomal RNA in Wheat Leaves
}

\author{
Myron K. Brakke, J. L. White, R. G. Samson and J. Joshi
}

Authors' addresses: M. K. BRAKKe, Departmen of Plant Pahology, 406 Plant Sciences Hall, University of Nebraska, Lincoln, NE 68583-0722 (U.S.A.). J. L. WhHTE, Microbiology and Plant Pathology Laboratory, BARC-West, Beltsville, MD 20705 (U.S.A.). R. G. SANSON, Department of Botany and Plant Pathology, Oregon State University, Corvalls, OR 97331 (U.S.A.). I. Josti, Biochemical Generies Branch, Bldg. 36, Room 1-C-06, NHLBI, NH, Bethesda, MD 20205 (U.S.A.)

Wich 2 figures

Received Jone 23, 1987; accepted November 17, 1987

\begin{abstract}
The amount of chloroplast 23 s rRNA relative to either DNA or to cytoplasmic 28s TRNA was reduced in young wheat leaves infected with wheat streak mosaic virus.

Chlorophyll was reduced in infected leaves. Fresh weight per leaf and DNA content per leaf were reduced in infected leaves, but DNA per $g$ was increased.

Cytoplasmic ribosomal RNA appeared to degrade more slowly during senescence in infected leaves than in uninfected. Virus was undetectable by density gradient centrifugation in systemically infected leaves less than $6 \mathrm{~cm}$ long and reached it highest concentration when young leaves reached their maximum size. Mosaic developed in leaves that became infected when $5 \mathrm{~cm}$ long or less. Since the entire leaf eventuatly developed mosaic, the events leading to mosaic occur after cell division, which is limited to the basal cria of young leaves.
\end{abstract}

\section{Zusammenfassung}

\section{Einfluß einer Wheat-Streak-Mosaikvirusinfektion auf die Gesamte-DNS} und die Chloroplasten Ribosomale-RNS in Weizenblättern

Festgestellt wurde eine Verminderung der Chloroplasten-23s r-RNS entweder bezüglich der DNS oder der cytoplasmatischen $28 \mathrm{~s}$ r-RNS in jungen Weizenblattern, die mit den Wheat-StreakMosaikvirus infiziert wurdem.

Der Chlorophyllgehalt, das Blattrischgewicht und der Blatt-DNS-Gehalt warde in befallenen Blättern reduziert, der DNS-Gehalt pro Gramm Blattmasse dagegen erboht.

U.5. Copyright Clearance Center Code Statement: $0931-1785 / 88 / 2302-0156 \$ 02.50 / 0$ 
Der cytoplasmatische ribosomale RNS-Abbau während der Blattseneszenz schien langsamer in befallenen als in nichtbetallenen Blättem.

Das Virus konte in systemisch infizierten Blattern, die kïzer als $6 \mathrm{~cm}$ lang waren, nach Dichtegradientzentrifugation nicht festgestellt werden. Die höchste Viruskonzentration wurde in jungen Blättern, die ihre volle Gröke erreicht haben, ermittelt. Mosaiksymptome entwickelten sich in Blätern, die zur Zeit der Infektion bis zu $5 \mathrm{~cm}$ lang waren. Da das ganze Blatt schließlich Mosaiksymprome aufweist, müssen die Ereignisse, die zur Mosaikentwicklung führen, nach der Zellteilung, dic im untersten $\mathrm{cm}$ eines jungen Blattes stattindet, eintreten.

Wheat streak mosaic virus (WSMV) causes disease in winter wheat in North America, Europe and Jordan (SLykHus 1967). The virus, a flexuous rod $700 \mathrm{~nm}$ long (BRAKKE 1971), is transmitted by eriophyid mites, Eviopbyes tulipae Keifer in North America and France (Slykhus 1953, Poinso et al. 1980) and in Yugoslavia by E. tosichella Keifer (Tosic 1973). The virus causes stunting of roots and tops of plants (LARSENet al. 1985) and yield losses up to $100 \%$ in infected areas of a field. The highest loss reported for a whole state was $7 \%$ for Kansas in 1981 (BRAKKE 1987).

Little is known about the physiological and cellular changes the virus causes in wheat plants despite the importance of wheat as a crop. Leaves with a mosaic have reduced amounts of chloroplast-associated proteins (WHITE and BRAkKE 1983). Ultrastructural studies have shown cytoplasmic cylindrical inclusions but few structural changes in chloroplasts (LEE 1965, MCMULLEN and GARDNER 1980). The cylindrical inclusions have a protein of Mr 66,000 (BRAKKE et al. 1987).

Mosaic is a development-related symptom that appears only in leaves that are systemically infected when very young. The expanding wheat leaf is a dynamic system with dividing cells in the basal $\mathrm{cm}$ followed by zones of chloroplast division and chloroplast maturation with mature cells at the leaf tip (DFAN and LEECH 1982). The pattern of development has been closely followed only for the first leaf (DEAN and LEECH 1982), but should be similar for subsequent leaves, though the absolute values of various parameters may differ. WILLAMS and RIJVEN (1965) reported that the amount of DNA per leaf increased with each succeding wheat leaf. There is no published information on variation of cellular parameters such as numbers of chloroplasts and ribosomes with leaf position or from plant to plant. Since mosaics appear only when developing leaves are systemically infected with virus, they may be the result of interference of the virus infection with metabolic processes (or genes expressed) unique to developing leaves.

We have investigated the content of chlorophyll, DNA, and cytoplasmic and chloroplast $r R$ NAs in segments of infected and uninfected wheat leaves at various stages of development to obtain further information on some of the cellular changes associated with mosaics.

\section{Materials and Methods}

\section{Virus maintenance and assay}

The Type strain of WSMV (PV57; ATCC 1981) and an isolate collected from the field in 1981 were mantained in wheat plants (Triticum aestivm L., cv. Michigan Amber'). Plants in the two-leaf 
stage were inoculated by leaf rubbing with juice from infected plants. Control plants were rubbed with water. Plants were grown, 5 per $10 \mathrm{~cm}$ pos, in a glasshouse kept at $25-30^{\circ} \mathrm{C}$. Unless otherwise stated, all assays were of combined leaves from 12 to 25 plants per experiment. Leaves were cut into 1 $\mathrm{cm}$ long segments, weighed, mixed, and randomly selected samples used for chlorophyll, rRNA, and DNA assays. The first leaf to appear, the coleoptile leaf, was called number 1 , the second, number 2 and so on. Virus concentration was estimated from the ultraviolet absorbance of the virus zone after density gradient centrifugation of extracts clarified by heating at $40^{\circ} \mathrm{C}$ and addition of Triton $X-100$ to a final concentration of $1 \%$ (BRAKKE and BALE 1968). Virus concentration in roots was compared with that in leaves by infectivity assay as described by BRAKKE (1958). The time needed for virus to become systemic was determined by removing the inoculated leaves from a portion of the plants at daily intervals and observing the plants for symptom development.

\section{Ribosomal RNA assay}

Leaves were ground in a Virtis homogenizer in 18 volumes $(\mathrm{ml} / \mathrm{g})$ of $110 \mathrm{mM}\left(\mathrm{NH}_{4}\right)_{2} \mathrm{CO}_{3}$, $330 \mathrm{mM} \mathrm{NH} \mathrm{Cl}_{4}, 11 \mathrm{mM}$ EDTA (ethylene diamine tetracetic acid), which had been adjusted to pH 9.3 with NaOH (BRAKKE 1972). The extract was filtered through cheesectoth, added to 2 volumes (ml/g) of $10 \%$ SDS (sodium dadecyl sulfate) and incubated at $25^{\circ} \mathrm{C}$ for $30 \mathrm{~min}$. Most proteins were removed by precipitation as potassium dodecyl sulfate complexes by addition of $5 \mathrm{M}$ potassium acetate $(\mathrm{pH} 8)$ to a final concentration of $0.3 \mathrm{M}$, incubation in an ice bath for $20 \mathrm{~min}$ and low-speed centrifugation (e.g. $10 \mathrm{~min}$ at $10,000 \mathrm{xpm} ; 9,000 \times \mathrm{g}$ average $\mathrm{RCF}$ ). Portions $(50-200 \mu 1$, depending on leaf age) of the clarified extract were centrifuged for $3.5 \mathrm{~h}$ at $54,000 \mathrm{rpm}(300,000 \times \mathrm{g}$ average $\mathrm{RCF})$ at $15^{\circ} \mathrm{C}$ in a Beckman sw60 rotor through a linear $7.5-30 \%$ sucrose gradient in NaGPS buffer $\left(50 \mathrm{mM} \mathrm{Na} \mathrm{NPO}_{4}, 100 \mathrm{mM}\right.$ glycine, $300 \mathrm{mM} \mathrm{NaCl}, 1 \mathrm{mM}$ EDTA, adjusted to $\mathrm{pH} 9.4$ with $\mathrm{NaOH}$ ). RNA concentrations were calculated from areas under peaks of ultraviolet absorbance scans of the gradients.

\section{DNA and chlorophyll assay}

DNA was determined by the diphenylamine assay (BURTON 1968) of extracts prepared by grinding leaves in a Virtis homogenizer in 20 volumes $(\mathrm{m} / \mathrm{g})$ of $2 \mathrm{M} \mathrm{NaCl}, 10 \mathrm{mM} \mathrm{EDTA}, 1 \%$ SDS, pH 7.O. After addition of an equal volume of chloroform, the mixture was again homogenized in the Virtis, and centrifuged to separate the emulsion. A portion of the aqueous layer was added to an equal volwme of isopropanol, incubated for $2 \mathrm{~h}$ at $-20^{\circ} \mathrm{C}$, and centrifuged to pellet the precipitate of nucleic acid. The pellet was washed once with $70 \%$ ethanol, dried in a partial vacuum, and suspended in $0.5 \mathrm{M}$ perchloric acid for the diphenylamine reaction. (ARNON 1949).

Chlotophyll was determined from absorbance at 663 and $645 \mathrm{~nm}$ of an extract in $80 \%$ acetone

\section{Results}

\section{Concentration of virus and development of symptoms}

The first systemic symptoms appeared in leaf 3 at 5 days after inoculation of plants at the 2-leaf stage. Leaf 3 was $2-5 \mathrm{~cm}$ long at 3 days after inoculation when the virus became systemic in half of the plants, as determined by excising the inoculated leaf from a portion of inoculated plants at daily intervals after inoculation. Therefore, events leading to mosaic occurred after this stage of leaf development.

The concentration of virus in immature leaves increased with leaf size, reaching a maximum of about $75 \mu \mathrm{g}$ per $\mathrm{g}$ of leaf in the youngest fully expanded leaf. Virus could not be detected by density gradient centrifugation in young leaves 4 and 5 when they were less than $6 \mathrm{~cm}$ long even though they developed subsequent to the first leaf to show mosaic and should have been systemically 
infected when they were a few mm long. The limit of detection was about $2 \mu \mathrm{g}$ of virus per gm of leaf. The virus concentration always decreased in leaves after they had stopped growing. Virus frequently could not be detected by density gradient centrifugation from old but still green leaves with mosaic symptoms. Therefore, virus multiplied more rapidly than it was degraded while the leaves were growing, but after the leaves had stopped growing, the reverse was true. Virus multiplication may have ceased in the old leaves.

The infectivity titre of virus in leaf extracts was 20 -fold higher (average of 4 experiments) than in root extracts of the same plants harvested 3 weeks after inoculation. Virus could not be detected in root extracts by density gradient centrifugation.
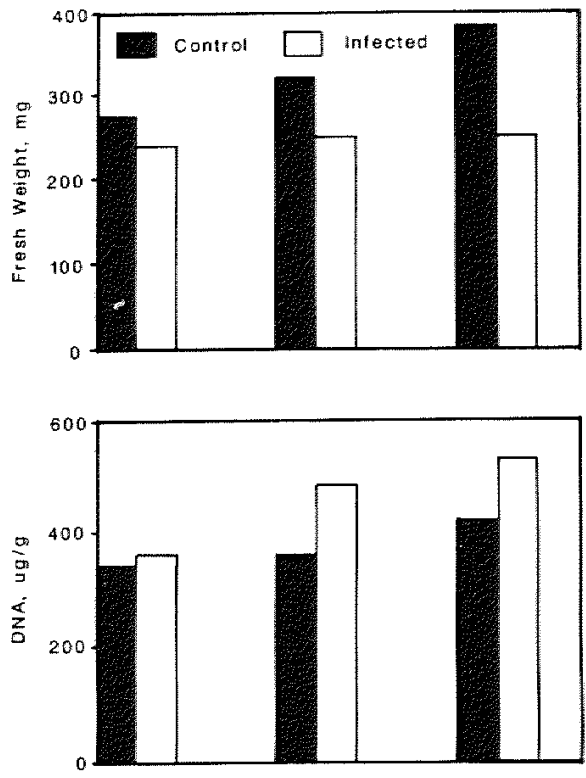

Fig. 1. Weight and DNA content of fully grown wheat leaves infected with WSMV. Values are averages of 3 experiments with 14, 25, and 26 plants per experiment, except for DNA content of leaf 3 which is based on 2 experiments. All differences between infected and uninfected leaves are significant, $P<0.05$, except for DNA per $g$ for leaf 3 and DNA per leaf for leaf 4

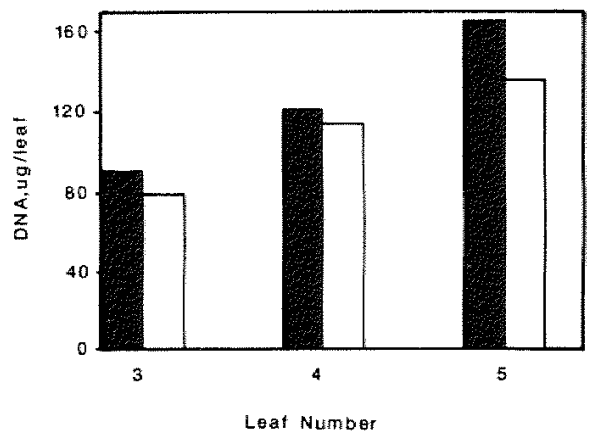




\section{Changes in DNA and weight of infected leaves}

Infected leaves had increased concentrations of DNA $(\mu \mathrm{g} / \mathrm{g})$, but decreased fresh weight and decreased amounts of DNA per leaf (Fig. 1). Differences were generally greater in leaves 4 and 5 than in leaf 3 which was the first leaf to show symptoms. The data in Fig. 1 are from 3 experiments with a total of 65 plants. Leaves were combined for assay in each experiment, a procedure which gives average values but no measure of variation from plant to plant in values for a given leaf. To obtain an estimate of the variation from plant to plant for use in statistical analysis, DNA and fresh weight of 36 individual leaves, each from a separate plant, were determined. The coefficients of variation were $12 \%$ for DNA content per gram or per leaf and $11 \%$ for fresh weight per leaf.

\section{The effect of WSMV infection on rRNA}

Sucrose density gradient centrifugation resolves chloroplast $23 \mathrm{~s}$ rRNA and cytoplasmic $28 \mathrm{~s}$ rRNA, but not the chloroplast $16 \mathrm{~s}$ and cytoplasmic $18 \mathrm{~s}$ rRNAs. Therefore, the $23 \mathrm{~s}$ and $28 \mathrm{~s}$ rRNAs were measured to follow the changes in chloroplast and cytoplasmic rRNAs, respectively. Immature leaves 4,5 and 6 of matched lengths from infected and uninfected plants were assayed for rRNA at 3 weeks after inoculation. The ratio of $23 \mathrm{~s} / 28 \mathrm{~s}$ rRNA was less in the infected than in the uninfected leaves in 19 of 21 such comparisons. The probability of obtaining 19 of 21 ratios that are less in the infected than in the uninfected is only 0.0002 if it is hypothesized that there is no difference. Therefore, the hypothesis is rejected. The ratio of $23 \mathrm{~s} / 28 \mathrm{~s}$ rRNA averaged $30 \%$ less in the infected than in the uninfected leaves.

The time course of change in concentration of both $23 \mathrm{~s}$ and $28 \mathrm{~s}$ rRNA with leaf age differed subtly between infected and uninfected leaves. The maximum concentration of rRNA was $2-2.5 \mathrm{mg}$ per $\mathrm{g}$ of leaf for very young leaves less than $7 \mathrm{~cm}$ long, either infected or uninfected. The concentration of rRNA per $\mathrm{g}$ of leaf decreased continuously as the leaf grew and then senesced. The total amount of $r$ RNA per leaf increased as the leaf grew, reached a maximum when the leaf reached its maximum length and then decreased. The ratio of chloroplast 23 s rRNA to cytoplasmic $28 \mathrm{~s}$ rRNA increased with growth of immature leaves, but less so in the infected than in the uninfected. After the leaf had reached full size, $r$ RNAs decreased less in the infected than in the uninfected. For example, in early experiments, both infected and uninfected leaves no. 4 had more of both rRNAs per leaf than corresponding leaves no. 3 , which were older and somewhat smaller. However, the difference between leaves 4 and 3 was greater in the uninfected than in the infected (data not shown). The difference could have been the result of slower degradation of rRNA in infected than in uninfected leaves, or a reflection of the greater degree of stunting of infected leaf 4 than of leaf 3 .

To eliminate ambiguities due to comparisons based on weight or on a per leaf basis, and to find if the decreased $23 \mathrm{~s} / 28 \mathrm{~s}$ rRNA ratio resulted from decreased $23 \mathrm{~s}$ rRNA or increased $28 \mathrm{~s}$ rRNA, the ratio of $\mathrm{rRNA}$ to DNA was determined in two experiments. Combined leaves from 12 to 20 plants per experiment were assayed for rRNA, DNA, and chlorophyll. The ratio of $23 \mathrm{~s}$ chloroplast rRNA to total 
Fig. 2. Chlorophyll, chloroplast $23 \mathrm{~s}$ TRNA, and cytoplasnic $28 \mathrm{~s}$ rRNA in in fected and uninfected wheat leaves harvested 12 days after inoculation. Symproms appeared 5 days after inoculation. Leaf 3 was mature and weighed $236 \mathrm{mg}$ (uninf) and $233 \mathrm{mg}$ (inf) in expt. 1 , and $187 \mathrm{mg}$ (uninf) and $184 \mathrm{mg}$ (inf) in expt. 2. Leat 4 was immature and weighed $128 \mathrm{mg}$ (uninf) and $107 \mathrm{mg}$ (inf) in expt. 1 and $162 \mathrm{mg}$ (aminf) and $118 \mathrm{mg}$ (inf) in expt. 2. DNA concentrations in $\mathrm{Hg}$ per $\mathrm{g}$ for leaf 3 were 339 (uninf) and 338 (inf) in expt. 1 , and 352 (uninf) and 334 (inf) in expt. 1, and for leaf 4 were 425 (unind) and 534 (inf) in expt. 1 . and 400 (uninf) and 415 (inf) in expt. 2. Leaves from 20 plants were combined for each extraction, except lor leat 3 of experiment 1 for which 12 leaves were used
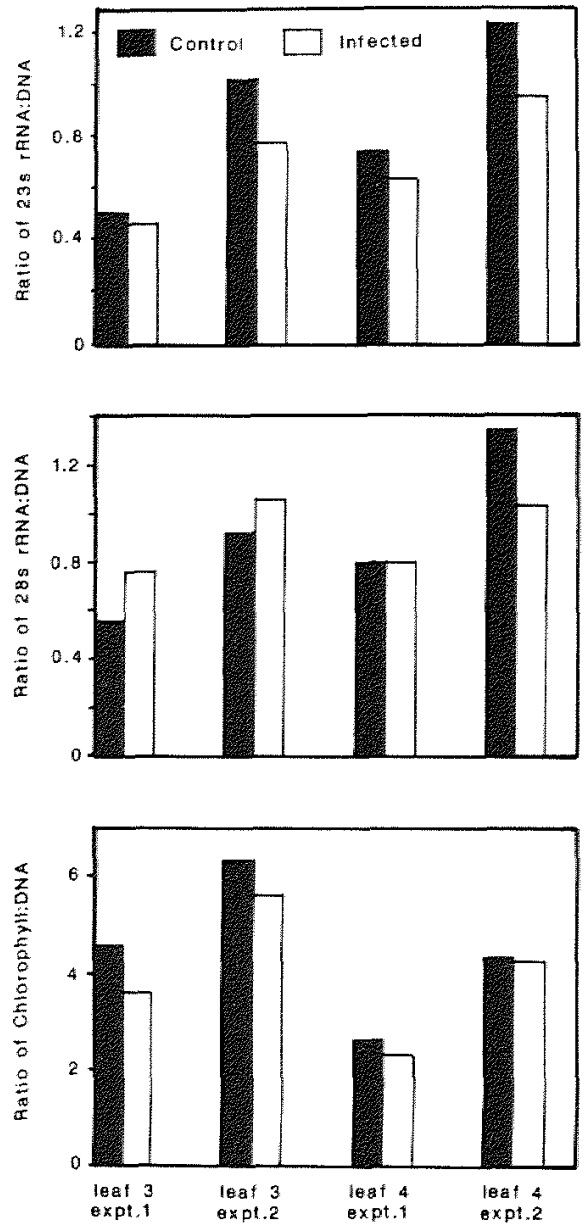

DNA was less in virus infected than in uninfected plants in both mature leaf 3 and immature leaf 4 (Fig. 2). Chlorophyll was also reduced, but not as much as the $23 \mathrm{~s}$ rRNA. The ratio of $28 \mathrm{~s}$ rRNA to DNA was higher in infected than in uninfected leaves in 2 of 4 comparisons and unchanged in a third. In both experiments, the amount of $28 \mathrm{~s}$ rRNA per unit DNA was the same for leaves 3 and 4 of infected plants. However, in the uninfected plants, leaf 3 had less $28 \mathrm{~s}$ rRNA per unit DNA than leaf 4 . Old infected leaves must have either a slower rate of degradation of $28 \mathrm{~s}$ RNA than uninfected leaves or an increased rate of synthesis.

Assays of whole leaves give average values for green and yellow areas. In two experiments, infected leaves fortuitously had larger than usual yellow areas. 
Assays of extracts of excised yellow areas showed a $23 \mathrm{~s} / 28 \mathrm{~s}$ rRNA ratio only $40 \%$ that of uninfected leaves, whereas the ratio for green areas of the same leaves was $80 \%$ of the uninfected.

\section{Discussion}

These results and the previous report of a reduction in chloroplast associated proteins (WHITE and BRAKKE 1983) supports the conclusion that systemic infection of wheat with WSMV interferes with chloroplast development. With one exception, previous reports on this topic have dealt with dicotyledons and viruses unrelated to WSMV. Decreases in chloroplast ribosomes or ribosomal rRNA on a per leaf or fresh weight basis have been reported for chinese cabbage infected with turnip yellow mosaic virus (REm and MatTHEws 1966), Nicotiana glutinosa L. infected with lettuce necrotic yellows virus (RANDles and Coleman 1970), N. tabaccum L. infected with tomato spotted wilt virus (MOHAMED and RANDLES 1972), N. tabaccum L. infected with tobacco mosaic virus (HIRAI and WildmaN 1969, OXFLFELT 1971, FRASER 1972), and barley infected with barley stripe mosaic virus (SUzUKI and TANIGUCHI 1973). Decreases were found in young leaves, but not always in old leaves. Fraser (1972) reported that old tobacco leaves from TMV-infected plants had more chloroplast IRNA than similar leaves from uninfected plants. Changes on a cellular basis have not been reported. FrasER (1972) found that DNA and leaf weight were reduced in infected leaves, but did not calculate rRNA as a ratio to DNA.

Our results show that the disruption of chloroplasts is not confined to pigments but extends to macromolecules, the proteins and nucleic acids. Reduction in chloroplast $\mathrm{rRNA}$ implies a reduction in chloroplast ribosomes including ribosomal proteins. Under the conditions of these experiments, the content of $28 \mathrm{~s}$ cytoplasmic rRNA per unit DNA was the same in immature leaves of infected and uninfected plants. However, mature leaves of infected plants had more $28 \mathrm{~s}$ rRNA per unit DNA than did comparable leaves from uninfected plants. WSMV infection may result in less than normal degradation of cytoplasmic ribosomes as leaves senesce.

Values of chlorophyll and rRNA expressed as ratios to DNA should give values similar to a per cell basis. WLLLIAMS and RIJVEN (1965) reported that $90 \%$ of wheat leaf cells are $2 \mathrm{C}$ (42 chromosomes), and 80 to $90 \%$ of total leaf DNA in nuclear (ELLS et al. 1983). Since chloroplast DNA may be reduced as a result of virus infection, total DNA probably is not exactly proportional to cell number. Nevertheless, we think DNA is a better basis for comparison than dry weight or wet weight. We attempted to make comparisons on the basis of counts of cells dispersed by chromic acid (BRown and Rickless 1949), but cell counts proved to be less reproducible than DNA assays. Cell counts showed a similar variation from plant to plant for a given leaf as did DNA assays (BRAKKE, unpublished results).

DNA was reduced in infected leaves, but not as much as fresh weight was reduced, suggesting both fewer and smaller cells per leaf. The third leaf to show 
symptoms was more stunted in regard to both DNA and weight than the first leaf to show symptoms. The previously reported decrease in dry weight of WSMVinfected plants (LARSEN et al. 1985) probably resulted from fewer and smaller cells per leaf as well as fewer leaves. Stunting occurs after mosaic symptoms appear and is a later stage in symptom development than damage to chloroplasts. The damage to chloroplasts is an early phenomenon that occurs in young (from $5 \mathrm{~cm}$ long to full length) systemically infected leaves where chloroplasts are developing as virus is rapidly multiplying. The damage to chloroplasts appears to occur after the cell division, which occurs in the basal cm of wheat leaves (DEAN and LEECH 1982).

If virus multiplication interferes with chloroplast development, it is logical to ask if proteins, nucleic acids or other components involved in chloroplast development are necessary for virus replication. The roots contained $5 \%$ as much virus as leaves, probably too much to be due to translocation. It may be concluded that chloroplast maturation is not an absolute requirement for virus replication, but roots do contain proplastids and the possibility of a role for proplastid component(s) in virus replication cannot be ruled out.

Cooperative investigation of the ARS, USDA, and the Nebraska Agriculural Experiment Station. Research conducted under project $21-3$ and published as Journal paper 8364 of the Nebraska Agricultural Experiment Station. Mention of a trademark or proprietary product does not constitute a guarantee or warranty by the U.S. Department of Agriculture and does not imply approval to the exclusion of other products that may also be suitable. The technical assistance of DiANE HOOPER is gratefuly acknowledged. Based upon research supported in part by the U.S. Department of Agriculture under Agreement Nos. 7801062 and 59-2177-1-1-718\%.

\section{Literature}

ATCC, 1981: American Type Culture Collection. Catalogue of Strains, II. Third ed.; publ by American Type Culture Collection, Rockville, Md. 29852.

ARnoN, D. I., 1949: Coppper enzymes in isolated chloroplasts. Polyphenoloxidase in Beta vulgarts. Plant Physiol. 24, 1-15.

BRAKEE, M. K., 1958: Properties, assay, and purfication of wheat streak mosaic virus. Phytopathology $48,439-445$.

- 1971: Wheat streak mosaic virus. C.M.I.A.A.B. Descriptions of Plant Viruses No. 48. Publ. by Commonwealth Mycological Institute, Kew, Surrey, England.

- - 1972: Slowly sedimenting infectious entities of southern bean mosaic virus. Virology 50 , $669-680$.

- -, 1987: Virus Diseases of Wheat. In: HEVME, E. G. (ed.), Wheat and Wheat Improvement, 2nd Edition. American Society of Agronomy Monograph No. 13, pp. 585-603. Publ. by American Society of Agronomy, Madison, Wisconsin.

- - and E. M. BALL, 1968: Purification and antigenicity of wheat streak mosaic virus. Phytopathology $58,963-971$.

$-\ldots,--$ Y. H. Hst, and W. G. LANGENEERG, 1987: Wheat streak mosaic virus cylindrical inclusion body protein. J. gen. Virology $68,281-287$.

BRowN, R., and P. RICKLESS, 1949: A new method for the study of cell division and cell extension with some preliminary observations on the effect of temperature and nutrients. Proc. Roy. Soc. London, Series B, Biol. Sci. 136, $110-115$.

BURTON, K., 1968: Determination of DNA content with diphenylamine. In: GROSSMAN, L., and Moldave, K. (Eds), Methods of Enzymology, Vol. 12, part B, pp. 163-165. Academic Press, New York. 
164 Mrron K. BRakke et al., Effect of Wheat Streak Mosaic Virus Infection on Total DNA

DEAN, C., and R. M. LeECH, 1982: Genome expression during normal leaf development. I. Cellular and chloroplast numbers and DNA, RNA, and protein levels in tissues of different ages within a seven-day old wheat leaf. Plant Physiol. 69,904-910.

ELLIS, J. R., A. J. JeLlings, and R. M. LEeCH, 1983. Nuclear DNA content and the control of chloroplast replication in wheat leaves. Planta 157, 376-380.

FRASER, R. S. S. 1972: Effects of two strains of tobacco mosaic virus on growth and RNA content of tobacco leaves. Virology 47, 261-269.

HIRAI, A, and S. G. WILDMAN, 1969: Effect of TMV multiplication on RNA and protein synthesis in tobacco chloroplasts. Virology $38,73-82$.

LARSEN, H. J., M. K. Brakke, and W. G. LANGENBERG, 1985: Relationships between wheat streak mosaic virus and soil-borne wheat mosaic virus infection, disease resistance, and early growth of winter wheat. Plant Disease 69, 857-862.

LEE, P. E., 1965: Electron microscopy of inclusions associated with wheat streak mosaic virus. J. Ultrastruct. Res. 13, 359-366.

MCMULLEN, C. R., and W. S. GakDNeR, 1980: Cytoplasmic inclusions induced by wheat streak mosaic virus. J. Ultrastruct. Res. 72, 65-75.

MOHAMED, N. A., and J. W. RANDLES, 1972: Effect of tomato spotted wilt virus on ribosomes, ribonucleic acid and Fration I protein in Nicotiana tabacum leaves. Physiol. Plant Path. 2, $235-245$.

OXELFELT, P., 1971: Development of systemic tobacco mosaic virus infection. II. RNA metabolism in systemically infected leaves. Phytopath. Z. 71, 247-256.

PolNso, B., B. Alliot, and P. A. SignORET, 1980: A mite-transmitted virus occurring on graminat in southern France. Proc. of Third Conference on Virus Diseases of Graminae, pp. 35-44. Rothamsted Expt. Sta., Harpenden, Herts., U.K.

RANDlEs, J. W., and D. F. COLEMAN, 1970: Loss of ribosomes in Nicotiana glutinosa L. infected with lettuce necrotic yellows virus. Virology $41,459-464$.

REID, M. S., and R. E. F. MATTHEws, 1966: On the origin of the mosaic induced by turnip yellow mosaic virus. Virology $28,563-570$.

SLYkHuis, J. T., 1953: Wheat streak mosaic virus in Alberta and factors related to its spread. Can. J. agric. Sci. 33, 195-197.

- - 1967: Virus diseases of cereals. Rev. appl. Mycol. 46, 401-429.

SUzUk, T., and T. TANIGUCH, 1973: Degradation of host high molecular weight RNA in barley leaves infected with barley stripe mosaic virus. Phytopath. Z. 77, 55-64.

Tosic, M., 1973: Transmission of wheat streak mosaic virus to different host plants by Aceria tosichella. P1. Prot. 126, 317-321.

WHITE, J. L., and M. K. BRAKKE, 1983: Protein changes in wheat infected with wheat streak mosaic virus and in barley infected with barley stripe mosaic virus. Physiol. Plant Path. 22, 87-100.

Williavs, R. F, and A. H. G. C. Rifven, 1965: The physiology of growth in the wheat plant. II. The dynamics of leaf growth. Aust. J. biol. Sci. 18, 721-743. 